\title{
Pivot to Asia: Key Role of Siberia
}

\author{
Timofei V. Bordachev \\ and Anastasiia V. Kazakova* \\ National Research University \\ Higher School of Economics \\ 20 Myasnitskaya Str., Moscow, 101000, Russia
}

Received 23.06.2016, received in revised form 20.09.2016, accepted 18.10.2016

Since the announcement of the pivot to Asia, enough time has passed to sum up the results and to evaluate the existing achievements and failures of Russia's new policy. However, despite some breakthrough, many issues remain open.

Most of the government's attempts in this area have not led to any fundamental changes, as the measures taken are often unsystematic and inconsistent. The majority of the actions are reactive, taken after the challenges have emerged. Therefore, further development of the region requires some more dynamic actions and larger strategy, where the central place belongs to Russian Far East and Siberia.

Thus, our task is to determine the content of the "pivot to Asia» policy, its possible directions and the main format.

Keywords: Siberia, pivot to Asia.

DOI: 10.17516/1997-1370-2016-9-11-2565-2574.

Research area: economics.

\section{Background information}

Since the Russian political authorities announced the external and internal political pivot to the East, enough time has passed to sum up the results and to evaluate the existing achievements and failures. The idea itself still remains one of the most disputed topics in Russian intellectual society: there have been multiple researches (Bordachev, Barabanov, 2012; Karaganov, Makarov, 2016) of the state opportunities and potential threats.

The new policy announced by the President of Russia ${ }^{1}$ was inspired by APEC summit in Vladivostok (2012), where Russia expressed a serious intention to take a more active part in the development of Asian Pacific Region, involving its territories of Siberia and the Far East. The changes emerged simultaneously in two policy lines, international and domestic. Thus, Russia succeeded in improving its relations with China to a record-breaking level of political trust and continuing cooperation with other Asian stockholders (India, Vietnam, Japan, South Korea, Indonesia etc.). In 2015, the Eurasian Economic Union (EEU) was founded, setting the objective to ensure the four freedoms and to form a single domestic market guaranteeing wealth to its citizens. A little later, Russia and China also

(C) Siberian Federal University. All rights reserved

* Corresponding author E-mail address: tbordachev@hse.ru; akazakova@hse.ru 
announced their readiness to "align with" the EEU and Silk Road Economic Belt (SREB), which includes execution of multiple infrastructure and investment projects in the Central Eurasia.

To solve internal political tasks, in the year 2012 the Ministry for Development of the Russian Far East was established, though at first its objectives and functions looked quite vague. In 2013, the Ministry approved the Russian Far East and the Baikal Region Social and Economic Development Programme, which was later substituted with the same-name document, but with a different volume of finance; instead of 3.8 trillion roubles, it intended to spend 346 billion only $^{2}$. Later, in its annual Address to the Federal Assembly, President Vladimir Putin articulated the concept of priority development areas (PDA), or zones with preferential conditions for foreign investment attraction. Since 2015, 9 more PDAs have been planned to be created in the territory of Russian Far East and Eastern Siberia. These areas offer foreign companies simplified administrative procedures and tax benefits. Therefore, Russia has set at least four tasks: to launch some investment programmes in cooperation with its foreign partners, to develop a chain of PDAs, to train high skilled human resources and to develop regional transport infrastructure.

But, despite all the achievements, many of the tasks remain incomplete. They require some actions for human resources development and attraction of foreign finance into the national economy. In its turn, it sets the question on the judicial system, transparent and trustworthy as it may be, and provision of technical and reference information of Russian and foreign businesses to both parties.

However, the majority of the government's efforts do not lead to any fundamental changes, as they are often unsystematic and inconsistent. The majority of the actions are reactive, taken after the challenges have emerged. Therefore, further development of the region requires some more dynamic actions and larger strategy, with the central role played by Russian Far East and Siberia.

Our task is to determine the gist of the "pivot to Asia" in Russian domestic and international policy, study its main trends and formats. However, answering what such action plan should consist of, we should say that it is active development of Siberian and Russian Far East's potential not just as a tool of penetration into Asian market, but also as a national priority of Russia, the future of the whole country may depend on at the modern stage. In other words, it may be described with the following formula: "pivot to Asia through the rise of Siberia and the Far East" (Karaganov, Barabanov, Bezborodov, Bordachev et al., 2016).

However, before articulation of a strategy and suggestion of an action plan, one should have a clear idea of the targets determined by the current problem. We see them as follows: Russia is in need for an impulse to develop a new socioeconomic development model and conditions for creating an advantageous external medium with no serious international political contradictions, but providing mutually profitable commercial and economic cooperation with other states. Consequently, actions shall be developed to achieve the mentioned objectives.

\section{Prerequisites for the new pivot}

It is not the first time Russia takes a turn to the East. Some attempts of making the resources of Eastern regions work at an extensive development stage have been made long before the Vladivostok summit. The first exploration of the lands (the territories to the East from the Urals) began back in the late $16^{\text {th }}$ century. But if, at first, the exploration of the lands was caused by some economic reasons (new sources of fur and new plough lands), later the military and strategic 
objectives came to the fore. In other words, the expanding Russian Empire needed to take some adequate measures to strengthen its borderlands located close to Japan (Treaty of Shimoda) and China (Treaty of Aigun and Convention of Peking).

Construction of the Trans-Siberian Railway gave a new push to the internal development of Siberia and the Far East. The emergence of throughways connecting the Eastern regions of the Empire to its European part established prerequisites for further development of trade, involving more human resources into increasing sustainability of the region (the Stolypin agrarian reforms and population of the territories located East from the Urals).

The Soviet era was the time when the main volume of industry was formed, turning Siberia and the Far East into the major power suppliers of the country: they had strategic coal mining sites and hydropower resources (Larin, 2015), which still retain their great significance for the country.

Along with that, economic development of the region has traditionally been hindered by such factors as scarce population and severe climate. However, neither of these closely interconnected factors is insuperable. The acute issue may be smoothened by means of development and transportation of industries and population to the Southern regions. Changes of the administration concept may also be productive: the state government is making a dramatic mistake, striving to rule a region located thousands of kilometres away from Moscow. The state is struggling to take active part in launching new programmes, attracting foreign partners, improving the peoples' lives and encouraging businesses. But it is evident that such centralization does not bring the expected results. Administration authority should be transmitted to the lower levels by encouraging self-administration initiatives of businesses and local politicians, self-organization of locals and their attempts to govern and develop their towns by themselves. These measures are expected to avoid further loss of human resources and to boost the long awaited economic growth.

As a result, with the enormous resource potential (mineral resources) of Siberia and the Far East, with the strategic energy resources (fuel, water resources) in their territories, wide opportunities for water-retaining and energyintensive industries we observe low quality of administration, absence of sustainable and efficient institutions. Unfortunately, the existing natural wealth is used unreasonably.

For this reason, a confident "turn" to Asia is based on some important factors. First of all, the global political and economic focus is shifting to the APR, and Russia, being a large political factor, cannot ignore this macrotrend. Thus, at the present moment the APR is producing around $40 \%$ of the GDP, and the expected average GDP increment rate in the region is $5-6 \%$, while the same indicator of the EU is $0.5 \%$, and that of the USA is $2.5 \%{ }^{3}$.

In the complicating relations with the Western countries, the diversification of international economic partners and entrance to the Asian market with the resource potential of Siberia and the Far East promise profitable prospects for Russia in the global scale. Due to the establishment of pragmatic and mutually profitable cooperation with the key APR countries, Russia may not just find the balance in its international policy, but also participate (and, consequently, obtain a voting right) in Asian affairs.

Moreover, as it has been mentioned, Russia is in need for a new development model right now, when the old one does not bring the expected results under the reducing prices for the globally used raw materials. For this reason, the pivot to the East and Asian economic growth may push Siberia and the Far East, turning them into a new 


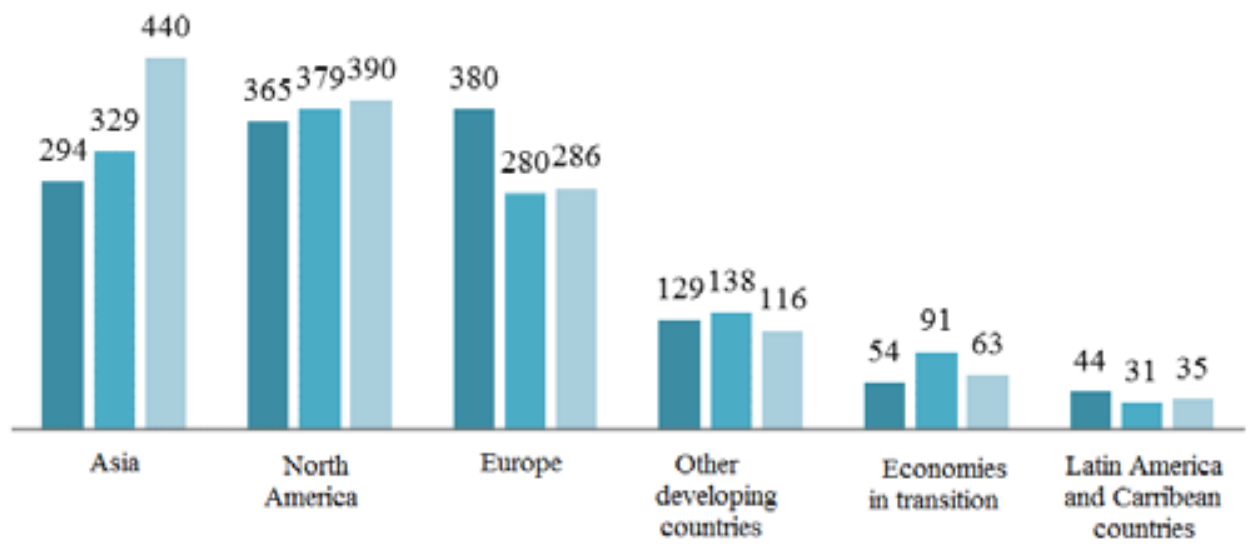

Fig. 1. Global Investment Trends 2012-20144, billion US Dollars

locomotive of Russian economy. This strategy is also necessary for the further development of the Eurasian integration project: the "alignment with" EEU and Silk Road Economic Belt (SREB) without a mature strategy and institutions ensuring the achievement of the goals may turn to be nothing but a bright prospective drawn on paper.

And, finally, the pivot to Asia is determined with Russia's desire to "get down to" its Eastern territories "for the long haul", as ignoring such wide and rich areas means killing the reducing Russian economy (Korolev, Huang, 2015).

The last of the described factors is well combined with the transformation Asia is currently going through. It takes active attempts to leave the model implying the use of cheap labour and resources for export-oriented industries and focus on consumer needs of the Asian societies acting as a base for economic growth. Asian countries do not choose to concentrate on producing primitive but massive goods, but prefer manufacturing hightechnology innovative products with high added value. Another important trend is the change of "Asia for the world" principle for "Asia for Asia" model (Bordachev, Sin, Likhacheva, 2015). In other words, money flows and investments are slowly re-oriented from the external trends to the ASEAN and South Asian markets. It happens, because the Asian Tigers (China, Japan, South Korea, Singapore, Hong Kong, Taiwan) themselves struggle for more independence (Wickett, Nilsson-Wright, Summers, 2015) in the fields of consumption, financial flow control, invention of innovations and patents, and creation of the medium for the improvement of human resources. It is accompanied with the rapid shift from interregional to intraregional trade (Sokh, 2012), which, to a certain extent, is connected to the reduction of demand in the developed countries after the financial and economic crisis of 2008-2009.

This way, the currently forming situation is favourable for the pivot to the East. The key event of the "pivot" shall be the rise of Siberia and the Far East, turning them into the engine for the future national growth.

\section{New role of Siberia and the Far East}

It is evident that Russia is choosing the path of becoming a large Eurasian power: we see it from the launched EEU project and the readiness to cooperate with China, Central Asian countries, Vietnam, India etc., developing the 


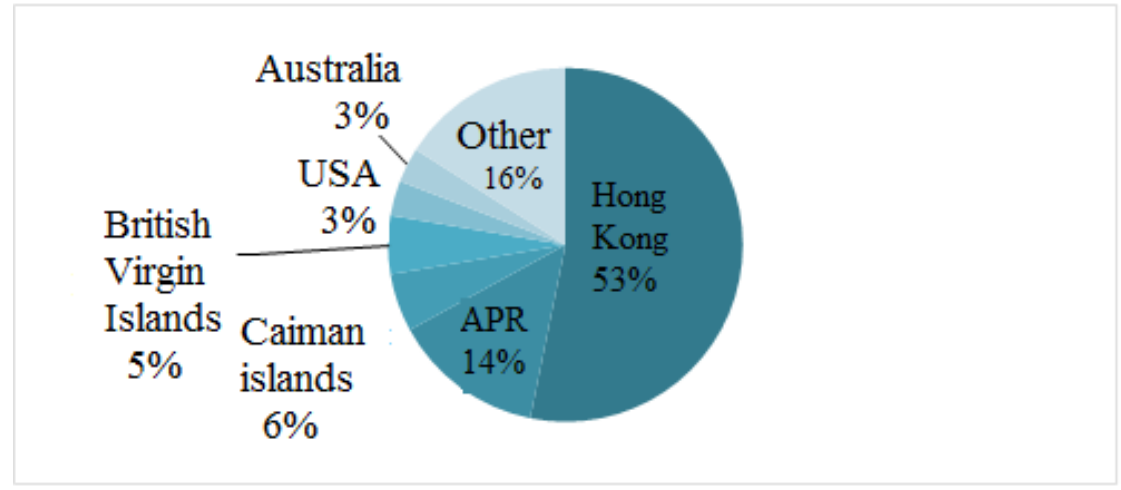

Fig. 2. Direct international investments of China in 2010-2013

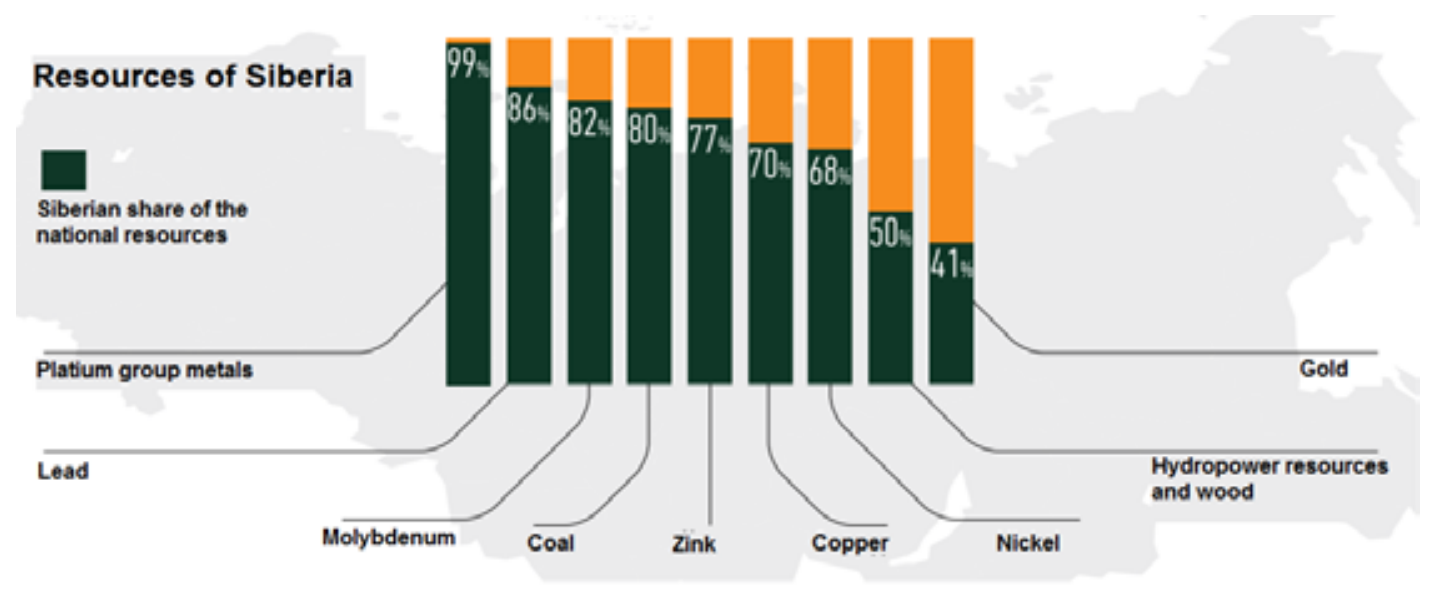

Fig. 3. Siberian share of the national resources ${ }^{6}, \%$

Great Eurasian region and confirming the serious intention of Russian political elite. However, it is important for the Eurasian programme concept to include the strategy of developing Siberia and the Far East.

The population of the Siberian Federal District is 19.2 million people; that of the Far East is around 6 million. Both regions are rich in natural resources. For instance, Siberia owns deposits of crude hydrocarbons, coal, uranium, ferrous, non-ferrous, rare-earth and precious metals, as well as wood, water and hydropower resources. The territories of Siberia and the Far East have enormous ploughlands, offering great opportunities for the development of high-added value industries.
Consequently, thedevelopmentstrategyneeds to consider the resource potential of the regions, but it should not be the key pillar of it. The typical Russian extensive way of land development should be replaced with the innovative type of products and services' production, where the existing resources of Siberia and the Far East are rationally and reasonably used without determining the ultimate result as a whole. Moreover, those are not the mineral resources that need to be the main component of growth, but the human resources. For this reason, the next step is creation of decent conditions for living and personal development in the territory of Siberia and the Far East, which includes, for instance, affordable accommodation construction, provision of adequate public 
health, social, educational facilities, leisure and entertainment centres. Moreover, it requires some dynamic actions to enhance economic activity, create conditions for comfortable development of small and medium businesses. Such solutions may limit the outflow of young and talented people needed for better future of the regions.

Siberia and the Far East shall be considered as tightly interconnected phenomena, as the growing disproportion of socioeconomic development of the regions leads to the aggravation of the current continental position of Siberia, i.e. to greater gap from the transport throughways and the infrastructure. Taking all that into account, it is important to understand, that the regions are different from each other in a number of factors (climate, density of population etc.), thereby requiring individual approach, taking local specificity into account for better result.

A logical consequence from the last point is a suggestion to shift the emphasis from the centralized to the regional administration method (but not substituting it completely). In other words, it is necessary to develop the key solutions and approve them at the local level, guided by the people involved into the process all the time. However, at the present moment a great influence on the resolution of these or those problems is made by Moscow authorities enjoying a monopoly right for the distribution of financial resources in the country. Moreover, the political landscape may be significantly changed by transporting the main state institutions and headquarters of large domestic companies from the European part of the country to Siberia and the Far East. Besides creating new jobs, such measures may aid the integration of the regions into the common Russian political context. Unfortunately, many people still imagine the Eastern territories of Russia as remote lands with a different lifestyle and more developed economic, commercial and cultural relations with the borderlands of other countries than those with the rest of Russia. Such attitude requires dramatic change: the strategy shall aid forming the image of Siberia and the Far East as a part of Russia and its integral part, but not as an isolated land living by its own rules.

One of the practical tools for the new policy implementation is the PDAs, including not just deregulation and provision of tax benefits for foreign investors, butalso complete transformation of Siberia and the Far East into the territory of economic freedom (Karaganov, Makarov, 2015). In its turn, such transformation requires a large scale of actions, such as anti-corruption measures, liberalization of the industrial branches attractive for foreign partners, development of a highly skilled labour pool and creation of conditions to stimulate migration of the necessary specialists.

It is worth saying that the current international situation is quite advantageous for the development of Siberia and the Far East. Considering the growth of population, and, therefore, the increase of domestic demand in China and India, many Asian countries are likely to face the lack of natural resources. In this situation, competitive advantages of Russian Eastern territories show a dramatic growth. Thus, China, Japan and South Korea do not produce any water-retaining products due to the lack of water, purchasing it from the countries where such products have lower self-cost, such as Russia. Siberia can produce relatively cheap and environmentally friendly hydropower energy. However, Russia's habit to supply primary raw material is a problem, while the prices for ready or processed products of the same raw material are growing. For this reason, it is necessary to change commercial and economic relations between Russia and Asia. As it is hardly possible to refuse exporting such goods under the growth of demand in Asian countries (Jong, 2014), a compromise would be to create joint enterprises in the territory of Siberia and 


\begin{tabular}{|c|c|c|c|c|c|c|}
\hline \multirow[t]{2}{*}{ No. } & \multirow[t]{2}{*}{ PDA title, location } & \multirow[t]{2}{*}{ Specialization } & \multicolumn{2}{|c|}{ Investments, billion RUB. } & \multirow[t]{2}{*}{ Jobs created } & \multirow[t]{2}{*}{ Area, ha } \\
\hline & & & $\begin{array}{c}\text { Private } \\
\text { (first residents) }\end{array}$ & $\begin{array}{l}\text { Budgetary } \\
\text { (total) }\end{array}$ & & \\
\hline 1 & $\begin{array}{l}\text { Predmostovaya, } \\
\text { Blagoveshchensk District, the } \\
\text { Amur Oblast }\end{array}$ & $\begin{array}{l}\text { Industrial and } \\
\text { logistic }\end{array}$ & 128.9 & 0 & 1530 & 857.3 \\
\hline 2 & $\begin{array}{l}\text { Belogorsk, } \\
\text { Belogorsk town, the Amur Oblast }\end{array}$ & Agriculture & 1.45 & 0.086 & 275 & 702.3 \\
\hline 3 & $\begin{array}{l}\text { Kamchatka, } \\
\text { Petropavlovsk-Kamchatsky City, } \\
\text { the Kamchatka Territory (Krai) }\end{array}$ & $\begin{array}{l}\text { Industrial- } \\
\text { logistic, tourism }\end{array}$ & 28.1 & 8.3 & 2918 & 1276 \\
\hline 4 & $\begin{array}{l}\text { Mikhailovskaya, } \\
\text { Mikhailovsky, Spassky, } \\
\text { Chernigovsky Districts, the } \\
\text { Primorsky Territory (Krai) }\end{array}$ & Agriculture & 39.03 & 4.44 & 2401 & 3151 \\
\hline 5 & $\begin{array}{l}\text { Beringovsky } \\
\text { Beringovsky District, Chukotka } \\
\text { Autonomous Okrug }\end{array}$ & $\begin{array}{c}\text { Mining } \\
\text { extraction } \\
\text { industry }\end{array}$ & 8.00 & 0 & 450 & 5960000 \\
\hline 6 & $\begin{array}{l}\text { Kangalassy Industrial Park } \\
\text { Yakutsk City, Republic of Sakha } \\
\text { (Yakutia) }\end{array}$ & Industrial & 1.11 & 0.2 & 350 & 16.9 \\
\hline & $\begin{array}{l}\text { Total (including the asset managem } \\
\text { contribution into the charter capita }\end{array}$ & nt company's & 206.59 & 13.03 & 7924 & 5966003.5 \\
\hline
\end{tabular}

Fig. 4. PDAs ready for launch, $2015^{7}$

the Far East, providing the capacity to produce energy-intensive and water-retaining products required for the APR countries and the access to innovations and new technologies interesting for Russia.

Finally, a special priority in the regional development strategy is the construction of transport skeleton of Siberia and the Far East including further entrance to the international market. It means emergence and expansion of the railway, motorway connection, aviation hubs, improvement of the existing infrastructure. Special attention shall be paid to creation and development of the "North-South" meridional transport and logistic corridors to export goods from the Far East and the North Siberia to China, as well as to export goods to such South Asian countries as Iran and India.

Besides development of transportation network of Siberia and the Far East connecting them to other Central Eurasian regions, it is important for Russia to offer its industrial, agricultural and intellectual goods and services to Asian market. For this reason, it seems reasonable for Russia to use the Siberian cluster potential, making Russian export less resource-oriented, but more diversified due to the production and offer of a greater range of goods. The clusters located in Siberia possess all necessary competitive advantages (sufficient electric power, mineral, fuel, water and ploughland resources) to attract external investments for creating new energyintensive and water-retaining industries.

All listed actions form the base for the new development strategy for Siberia and the Far East, the huge potential of which is impossible to overestimate. As usual, there is no time for making mistakes, so all the actions taken in the currently adverse international economic conditions shall be consistent and systematic. 
We need dynamic, but brand new measures, designed for long-term creation of a new medium with comfortable living conditions for the people, and innovative economy based on rational use of natural and human resources, not a one-time effect. And, most importantly, such strategy shall lay the foundation for the new concept of Siberia and the Far East: it's time to put an end to the "hermitage" of these territories. Being an organic part of Russia, they are quite likely to become the "trademark" of Russia in the new future.

\section{Conclusion}

The pivot to Asia is just getting started, and despite some lost opportunities, the forming medium is advantageous for Russia to make its next long awaited "leap". It is advantageous in the sense that it forces the country and its political power to act in the extremely unpredictable conditions, to mobilize all necessary resources when there is no time to hesitate and the only power to rely on is its own.

Moreover, it is necessary to understand what the new policy includes. Inclination to Asia means, first of all, some opportunities both outside (in the APR, ASEAN countries) and inside the territory of Russia. Here we speak of the new impulse for economic growth, mutual investments, capital and labour markets development, cooperation with ASEAN for technologies and innovative product development, establishment of a trustbased political dialogue as well as the opportunity to guarantee peace and prosperity to its citizens.

For Russia, this task is twice as relevant; the objectives it sets are larger than just "participation in Asian affairs". The objective is to perform the national task, which is the rise and long-awaited development of Siberia and the Far East which are expected, at the present stage, to inherit the role of a locomotive for Russian economic growth. Inclusion of Russian Eastern regions' development strategy into the "pivot" concept is intended to make this process systematic and nonreversible, as the current diverse and inconsistent legislative measures are obvious not to bring the expected results.

And, finally, the pivot to the East is not a synonym for turning away from the rest of the world. Even despite the cooling relations with Western partners, Russia should and it will develop cooperation in both directions, without limiting itself to one of them. The success depends on how clear the task is. For Russia, the ultimate goal, along with many others, is the following: establishment and development as a Eurasian Asian-Pacific power with the "smart economy" and great human potential. The work is just getting started.

\footnotetext{
Putin, V.V. (2013) Poslanie Prezidenta Federal'nomu Sobraiiu [President's Address to the Federal Assembly], December 12, 2013. URL: http://kremlin.ru/events/president/news/19825; Putin, V.V. (2014) Poslanie Prezidenta Federal'nomu Sobraniiu [President's Address to the Federal Assembly], December 4, 2014. URL: http://kremlin.ru/events/president/ news/47173 (accessed 05.05.2016).

2 Postanovlenie Pravitelstva RF № 308 (15.04.2014) «Ob utverzhdenii gosudarstvennoy programmy Rossiyskoy Federatsii «Sotsial'no-ekonomicheskoye razvitiye Dal'nego Vostoka i Baykal'skogo regiona» [Government Resolution of April 15, 2014№ 308 «On approval of the state program of the Russian Federation «Social and economic development of the Far East and the Baikal region»] Available at: http://government.ru/programs/232/events/ (accessed 5 June 2016)

3 Analytics. Euromonitor International. URL: http://go.euromonitor.com/Euromonitor-Analytics.html (accessed 05.05.2016).

4 UNCTAD Global Investment Trends Monitor, No.19. May 2015.

5 Data. National Bureau of Statistics of China. URL: http://www.stats.gov.cn/english/Statisticaldata/AnnualData/ (accessed 05.05.2016).

6 Strategiia Sibiri. Ofitsial'nyy sayt polnomochnogo predstavitelia Prezidenta RF v SFO [Strategy of Siberia. Official Website of the Authorized Representative of the RF President in the SFD] URL: http://sfo.gov.ru/okrug/ekonomika/strategiya/ (accessed:05.05.2016).

7 Territoriia operezhaiushchego sotsial'no-ekonomicheskogo razvitiia (TOR). Ministerstvo RF po razvitiiu Dal'nego Vostoka [Priority Socioeconomic Development Areas (PSDA). The Russian Federation Ministry for the Development of Russian Far East] URL: http://minvostokrazvitia.ru/activities/toser.php (accessed May 05, 2016).
} 


\section{References}

Analytics. Euromonitor International. Available at: http://go.euromonitor.com/EuromonitorAnalytics.html (accessed 5 June 2016)

Bordachev, T., Barabanov, O.(2012) Toward the Great Ocean, or the New Globalization / Ed. By S. Karaganov. Moscow: Valdai Discussion Club.

Bordachev, T., Likhacheva, A., Zhang Xin. (2015) What Asia wants, or the "Four C's»: Consumption, Connectivity, Capital and Creativity. Moscow, Russia in global affairs, 2015. Available at: http://eng.globalaffairs.ru/valday/What-Asia-wants--or-the-Four-Cs-Consurnption-ConnectivityCapital--Creativity-17564

Cox, M. Power Shifts, Economic Change and the Decline of the West? In: International Relation 26(4), 2012. pp.369-388.

Data. National Bureau of Statistics of China. Available at: http://www.stats.gov.cn/english/ Statisticaldata/AnnualData/ (accessed 5 June 2016)

Jong Ho Hong, Changhun Kim, Heeyoung Shin (2014). Power sector in developing Asia: current status and policy issues. In: ADB Economics, working paper series. No. 405.37 p.

Karaganov, S., Barbanov, O., Bezborodov, A., Bordachev, T., Kazakova, A., Likhacheva, A., Lukin, A., Makarov, I., Piatachkova, A., Skriba, A., Sokolova, A., Suslov, D., Timofeev, I. (2016) Toward the Great Ocean - 4: Turn to the East. Preliminary results and new objectives/ Ed. By S. Karaganov. M.: Valdai Discussion Club.

Korolev, A. Huang, J.(2015) Introduction: Russia's New Pivot to Asia and Potential for International Cooperation. In: International Cooperation in the Development of Russia's Far East and Siberia / ed. By J. Huang, A. Korolev. NY:Palgrave Macmillan, 2015. pp. 1-15, doi: 10.1057/9781137489593_1

Karaganov, S., Makarov, I. Povorot na Vostok: itogi i zadachi [Pivot to the East: results and challenges]. In: Rossiyskaya gazeta. Available at: http://rg.ru/2015/02/06/povorot.html

Larin, V. (2013) Vneshniaia ugroza kak dvizhushchaia sila osvoeniia i razvitiia Tikhookeanskoy Rossii [External threat as the driving force of developing Pacific Russia]. Moscow, Carnegie Moscow Center, $35 \mathrm{p}$.

Makarov, I., Barabanov, O., Bordachev, T., Kanaev, E., Larin, V., Ryzhkov, V. (2014) Toward the Great Ocean - 2, or Russia's Breakthrough to Asia/ Ed. By S. Karaganov. M.: Valdai Discussion Club.

Postanovlenie Pravitelstva RF № 308 (15.04.2014) «Ob utverzhdenii gosudarstvennoy programmy Rossiyskoy Federatsii «Sotsial'no-ekonomicheskoye razvitiye Dal'nego Vostoka i Baykal'skogo regiona» [Government Resolution of April 15, 2014№ 308 «On approval of the state program of the Russian Federation «Social and economic development of the Far East and the Baikal region»] Available at: http://government.ru/programs/232/events/ (accessed 5 June 2016)

Putin, V. Poslanie Prezidenta Federal'nomu Sobraniu [Address to the Federal Assembly] Available at http://kremlin.ru/events/president/news/19825 (accessed 5 June 2016)

Putin, V. Poslanie Prezidenta Federal'nomu Sobraniu [Address to the Federal Assembly] Available at http://kremlin.ru/events/president/news/47173 (accessed 5 June 2016)

Strategiia Sibiri. Ofitsial'nyy sayt polnomochnogo predstavitelia Prezidenta RF v SFO [Strategy of Siberia. Official Website of the Authorized Representative of the RF President in the SFD] URL: http://sfo.gov.ru/okrug/ekonomika/strategiya/ (accessed:05.05.2016). 
Territoriia operezhaiushchego sotsial'no-ekonomicheskogo razvitiia (TOR). Ministerstvo RF po razvitiu Dal'nego Vostoka [Priority Socioeconomic Development Areas (PSDA). The Russian Federation Ministry for the Development of Russian Far East] URL: http://minvostokrazvitia.ru/ activities/toser.php (accessed May 05, 2016).

UNCTAD Global Investment Trends Monitor, No.19. May 2015.

Wickett, X., Nilsson-Wright, J., Summers, T. (2015) The Asia-Pacific Power Balance. Beyond the US-China Narrative. Research Paper. Chatham House, September 2015. 78 p.

\title{
Поворот на Восток: \\ ключевая роль Сибири
}

\author{
Т.В. Бордачев, А.В. Казакова \\ Национальный исследовательский университет \\ Высшая школа экономики \\ Россия, 101000, Москва, ул. Мясниикая, 20
}

С момента объявления российским политическим руководством поворота внешней и внутренней политики России на Восток прочло достаточно времени, чтобы можно было подводить некоторые итоги и переосмысливать достигнутые успехи и неудачи. Но, несмотря на все достижения, многие задачи по-прежнему остаются невыполненными.

Большинство попыток правительства на данном направлении не приводят к фундаментальным изменениям, поскольку зачастую носят несистематический и непоследовательный характер. Все действия, как правило, являются «реактивными», т.е. следуют за возникающими проблемами и вызовами, а не предвосхищают их. Дальнейщее развитие и рост благосостояния региона требуют более динамичных мер в рамках масштабной стратегии, в которой иентральное место отведено как раз Дальнему Востоку и Сибири.

Нашей задачей является определить содержание «разворота к Азии» российской внутренней и внешней политики, его возможные направления и формат.

Ключевые слова: Сибирь, поворот на Восток.

Научная специальность: 08.00.00 - экономические науки. 